Elsevier required licence: (C) <2018>. This manuscript version is made available under the CC-BY-NC-ND 4.0 license http://creativecommons.org/licenses/by-nc-nd/4.0/ 


\title{
Reforms to counter a culture of secrecy: Open government in Australia
}

\begin{abstract}
Governments for most of recorded history have surrounded their information and decisionmaking with a culture of secrecy. By the latter half of the $20^{\text {th }}$ century western liberal democracies, driven by right-to-know movements, slowly moved away from secrecy toward more openness of government through public access to its information. Australia, with a series of reforms beginning in the late 1970s, declared in 2010 that government information was a national resource, and public access was the default position. This paper, by providing a history of the Australian Commonwealth legislative and regulatory reforms, their impetus and interpretations, explores the ebb and flow of openness and the intended and sometimes unintended, consequences for traditional government secrecy. Using the complete freedom of information datasets made available by these reforms, the paper presents an insight into government attitudes to openness by providing access to its information. These datasets also enable research into government and bureaucratic actions to pushback against these reforms for pragmatic or ideological reasons. The paper concludes that although there continues to be worrying vestiges of secrecy, on balance, Australia has achieved much in countering a culture of secrecy and the delivering more openness of government.
\end{abstract}

\section{Keywords}

Freedom of information, right to know, secrecy, privacy, open government

\section{Introduction}

Open government, the twentieth century zeitgeist of liberal, democratic societies, promises transparency, the empowerment of citizens, the fight against corruption, and the 
harnessing of new technologies to strengthen governance. ${ }^{1}$ Rulers throughout history have collected information for practical, legal and administrative purposes, in the interests of state stability, taxes, economic development and trade. Sometimes this information was about the people they governed and sometimes it was non-personal information, still the normative practice of contemporary governments. However, in the main these records were available only to the ruler and his bureaucrats. Secrecy was the norm. The gradual eroding of secrecy as a normative practice is a relatively recent phenomenon that builds on the liberal ethos of Thomas Hobbes, Edmund Burke and John Stuart Mill and on the movements of the eighteenth century when the revolutions in England and France fostered questioning the legitimacy of absolute autocracy and state secrecy.

One of the drivers that challenge state secrecy is the demand for information, which, in turn, drives reform that delivers more demand, often with unexpected impact and consequences that include demands for further reform. This paper proposes that reforms are often incremental with an ebb and flow nature; that government policy adoption and implementation "do not operate in a vacuum" (Julnes \& Holzer, 2001, p. 696). There are many factors that influence these incremental changes, not all of which are legislative or regulatory. As Kreimer (2008) points out there are other actors who affect the governmental reform process - bureaucrats, national and international institutions, an open media and civil society actors who pursue campaigns for transparency and the right to know. One must also consider political and commercial factors and the implications of self-interestedness. An early and long-lasting action for opening government policy discussions to the public was in 1783 when the ban on the 4th estate taking notes of English parliamentary debates was lifted. This reform enabled greater public scrutiny of parliamentary proceedings, leading to disquiet

\footnotetext{
${ }^{1}$ Open Government Partnership, https://www.opengovpartnership.org/about/
} 
among the parliamentarians. Ultimately, in an act of commercial and political expediency, William Cobbett, a publisher, persuaded the parliamentarian William Windham that Cobbett's Parliamentary Register would be politically important as a check upon the proministerial newspapers. In time Cobbett's Parliamentary Debates, became the official parliamentary record, the precursor of contemporary official Hansards (Grande, 2014, p. 47). While the public parliamentary debates are still recorded and available to the public, as we shall see, non-public deliberations and decision-making processes are not; they remain secret and exempt from disclosure.

It is also difficult to discount the disruptive and transformative power of technologies in driving reform; the invention of the printing press leading to the reformation movement comes to mind. Analogously, much of the current discourse around the concept of open government focusses on e-government which of its nature demands more and more access to information; as Castells remarks "reform of the public sector commands everything else in the process of productive shaping of the network society. This includes the diffusion of egovernance (a broader concept than e-government because it includes citizen participation and political decision-making)" (Castells \& Cardoso, 2006, p. 17). And indeed, many of the recent major reforms for greater access to government information in Australia were driven by the 2009 Government 2.0 Taskforce set up to examine how the collaborative tools of the Web could achieve open, accountable, responsive and efficient government (Gruen, 2009).

The paradox is the pushback against reform to self-interested secrecy. Selfinterestedness can be about power, expediency or cynicism. As Weber memorably commented "every bureaucracy seeks to increase the superiority of the professionally informed by keeping their knowledge and intentions secret" (Weber, 1946, 2009, p. 223), or in the words of Gordon Brown freedom of information "can be inconvenient, at times frustrating and indeed embarrassing for governments" (2007). The Government 2.0 
represented "a shift to an assumption that government information is open by default, in the absence of good reasons to the contrary" (Gruen, 2009, p. 4); it is these reasons that are the basis of often controversial decisions that cause or underpin resistance to openness and perpetuate the perception that there is still a culture of secrecy.

This paper gives an overview of Australian reforms that were designed to enable access to Australian public sector information, specifically Commonwealth government information. In this context government information consists of all information products in any format, generated, created, collected, processed, preserved, maintained, disseminated, or funded by the Commonwealth (Gruen, 2009, p. 4). It recognises that at various times, some of this information may not necessarily be publicly available because of the constraints of other policies; policies such as intellectual property (IP) rights, national security or personal privacy. It is often the case that these same policies are also subject to reform-relaxing, narrowing or interpreting — and the determination of what is openly accessible to citizens. The paper explores the gambit of reforms that were born out of ideals and pragmatism, and then examines the factors that militate against these same ideals - realism, expediency, ideology and, possibly, cynicism; or as Worthy (2017) provocatively wonders "how and why governments pass laws that threaten their power".

\section{Thirty years of access to information reform}

Secrecy laws that impose obligations of confidentiality on individuals handling government information - and the prosecution of public servants for the unauthorised disclosure of such information - can sit uneasily with the Australian Government's commitment to open and accountable government. Secrecy laws have also drawn sustained criticism on the basis that they unreasonably interfere with the right to freedom of expression (Australian Law Reform Commission (ALRC), 2009, p. 21) 
According to Paul Finn (1991, p. 90), in Australia "official secrecy has been the legislatively enforced norm". The first colonial secrecy provision, Victoria 1867, required that "no information out of the strict course of official duty shall be given directly or indirectly, by any officer without the express direction or permission of the responsible Minister", a secrecy mechanism that continued, until the reforms of 2010, in the guise of ministerial vetoes and conclusive certificates. Furthermore, in Australia, a Westminster system of government, all "documents prepared by Crown servants become Crown property and, as such, matters which the Crown could disclose or withhold at will" (Campbell, 1967, p. 77). It should be noted that while a non-Westminster system such as the United States where works of the Federal Government do not have copyright protection (s 105 of the US Copyright Act 1976), it doesn't necessarily mean that it is made available or disseminated to the public (for a comparative discussion see Gilchrist, 2012). By the time of Australian federation in 1901, McGinness (1990) notes that the first federal secrecy provisions were legislated in the Commonwealth Post and Telegraph Act 1901 and, based on the British Official Secrets Act, continued primarily to be concerned with defence and security. However, after World War II as the role of the Australian Commonwealth expanded into other areas "such as taxation, health, education, welfare, scientific research, industry assistance and regulation, secrecy provisions increased in number as a reflection of the increase in personal and commercially sensitive information collected by the government" (ibid.1990, p. 49). A further consequence of this expanded role was the new provisions for the management of government information. Until the twentieth century, most government records were collected and housed in government administrative units. It was not until World War II that the decision was made to establish a Commonwealth archives housed within the Commonwealth Library, later the National Library of Australia, and in 1961 a separate institution was set up, finally to become the National Archives of Australia in 1974 
(Cunningham, 2005). This, therefore, is the background to the reforms that brought about huge changes in the access to government information in Australia.

Beginning in the $1960 \mathrm{~s}$, the reforms were part of a gradual movement that can loosely be brought under the umbrella of the 'right to know' movements of the second half of the twentieth century and accelerating in the first decade of this century. There were two major periods of reform; the mid-1970s and early1980s when new laws were developed to enforce government accountability, including the Administrative Appeals Tribunal Act 1975, the Ombudsman Act 1976, the Administrative Decisions (Judicial Review) Act 1977, and the proposed Freedom of Information Bill (Thynne \& Goldring, 1981). In 2009-2010 a second tranche of major reforms, riding on the open government movement, provided, at least in theory, the greatest openness in Australian history. In 2011, the Commonwealth declared that government information is a national resource and that "open access to information [is the] default position" (Office of the Australian Information Commissioner (OAIC), 2011).

Several of the most far-reaching of these reforms - the Archives Act 1983 (Cth), the Freedom of Information Act 1982 (Cth), the Privacy Act 1988 (Cth), Freedom of Information (Reform) Act 2010 (Cth), the Information Commissioner Act 2010 (Cth), and the Statement of Intellectual Property Principles for Australian Government Agencies 2010 — successfully challenged and loosened state secrecy. I have already suggested that increased reform can impact government processes and citizens' demands in both predictable and unforeseen ways. As Stewart pointed out, parliamentary committees in their deliberations on more access to government information through legislation "fail[ed] to engage with the extent passage of the FOI Act might itself encourage further change and the implications that may have" (2015, p. 104). To suggest that these reforms are inherently related, one can quote the first recommendation of the 2013 Hawke Review of the 2010 FOI reform legislation: that a comprehensive review be undertaken in which it "might also consider interaction of the FOI 
Act with the Archives Act and the Privacy Act and other related legislation" (Hawke, 2013, p. 4). The following section briefly describes each of these legislative reforms in order to examine their consequences and the ramifications for the longstanding culture of secrecy in Australia.

\subsection{Accessing the archive}

There is no political power without control of the archive . . Effective democratization can always be measured by this essential criterion: the participation in and access to the archive, its constitution, and its interpretation (Derrida, 1996, p. 4)

While not chronologically the first Commonwealth Act in reducing the culture of secrecy, the Archives Act had the longest gestation period. The first Australian Archives Bill was put forward by the Commonwealth library committee in 1927 as a measure to prevent destruction of departmental government records, but it never reached parliament (National Archives of Australia, n.d., para. 2). As I have already noted, a formal war archive had been set up in 1945 to prevent the loss of war records that occurred after World War I, but there was little apparent consideration given to enabling public access. However, in 1966 following the new British Public Records rules, a fifty year moratorium on access to the records was established by the Cabinet (ibid., para. 13). But it was not until the early 1970s that any statutory provision was made for the archiving of government records, although during this period various measures were drafted to provide public access to them. One of these was to establish the 30 year rule, reducing by twenty years the length of time that government records could be kept secret, after which, in principle, many of the records become available to the public (the open access period). According to MacFarlane and Antsoupova (2013), over the ten years of drafting an archive bill, it was always accepted that the bill was part of a “"package' of administrative law measures" that needed to consider public access to the records. Of greatest importance were 1) a Freedom of Information Act that could cover 
circumstances in which records could be made available even though they did not fall into the open access period, and 2) an Administrative Appeals Tribunal Act to enable reviews of administrative and executive decisions, including access to government-held information, including information about citizens.

Australian common law neither defines nor recognises a right to privacy (Taylor, 2000) and McGinness concluded that as the government expanded its collection of personal and commercially sensitive information, it had the "undesirable effect in reinforcing an atmosphere of official secrecy within government" (1990, p. 89). In 1976 the Liberal party requested that the Law Reform Commission (now the Australian Law Reform Commission) inquire into the "extent to which undue intrusions into or interferences with privacy arise or are capable of arising under the laws of the Commonwealth Parliament ..." (ALRC, 1983, p. xxxvi). The massive report was published in 1983 and in 1988 Australia's first Privacy Act was introduced as a direct response to a highly controversial proposal in 1985 for a national identity card (the Australia card) that would enable a "matching process" of personal data held in various systems across government departments (Greenleaf \& Nolan, 1986, p. 412). The Privacy Act of 1988, while extensively amended over the years, its original form, based on the 1980 OECD Guidelines on the Protection of Privacy and Transborder Flows of Personal Data (OAIC n.d., para. 3), was to protect personal information held in government agencies and to set standards for its collection, storage, use and disclosure, and its correction. It is information privacy rather than surveillance privacy that is the focus of this paper.

Both privacy and freedom of information legislation, as we shall see, are mechanisms for providing and restricting access to government-held information, but their remits can overlap and may lead to friction. In some cases, information that would be withheld under privacy legislation may be required to be disclosed under FOI; or the converse, personal rights to information can be exempt from disclosure under freedom of information (Paterson, 2005). 
This paper will examine in detail how, without an exquisite balancing of these conflicting positions, often requiring rulings from the High Court, there can be an abuse of bureaucratic power and reversion to government secrecy.

\subsection{Legislating against secrecy}

Australia was the second country to pass freedom of information (FOI) legislation and the first in a Westminster system of democratic government. The Freedom of Information Act 1982 (Cth) was the culmination of a twenty-year process that included right to know campaigns, political posturing, visionary idealism, and ultimately, public disquiet concerning the secrecy of government's decision-making about the Vietnam war, when a former Prime Minster, Gough Whitlam declared in a political campaign that

the Australian Labor Party will build into the administration of the affairs of this nation machinery that will prevent any government, Labor or Liberal, from ever again cloaking your affairs under excessive and needless secrecy (Whitlam, 1972)

The United States 1966 FOI Act had provided the impetus for formal considerations of similar legislation for Australia, considerations that included a Royal Commission in 1976, two interdepartmental committees in 1974 and 1976 and in 1979 a parliamentary committee (Australian Law Reform Commission (ALRC) 1995). Once passed, there was great enthusiasm for the legislation, which, after a few years, gradually dissipated. As we shall see the reasons for this are varied and some were addressed in following decades, culminating in a package of radical reforms in 2009-2010, in particular the Freedom of Information Amendment (Reform) Act 2010, the Information Commissioner Act, and the Statement of Intellectual Property Principles for Australian Agencies.

But to begin at the beginning, the original FOI legislation was almost immediately criticised for its apparent restrictive approach through the mechanism of ministerial vetoes and 'conclusive certificates' and subsequent very high level of appeals (Hazell \& Worthy, 
2010, p. 358). It can be assumed that much of this criticism was levelled at the restrictive access to government information, although it was not until 2000 that requests for government or policy-related information were separated from requests for personal information. While the Act provided for a number of exemptions from disclosure in areas of international affairs, national security and cabinet deliberations, the issue of ministerial conclusive certificates, that is, certificates establishing conclusively that a document is exempt and therefore preventing a review of the decision, was to be the basis of reform agendas for thirty years. Even before the passing of the legislation, the Senate Standing Committee on Legal and Constitutional Affairs (SSCLCA) noted in its review of the 1979 Bill that

there is no justification for such a system tailored to the convenience of ministers and senior officials in a Freedom of Information Bill that purports to be enacted for the benefit of, and to confer rights of access upon, members of the public. This can only confirm the opinion of some critics that the bill is dedicated to preserving the doctrine of executive autocracy (SSCLCA 1979, p. 180).

Furthermore, the reliance on an argument that conclusive certificates protected the public interest was scathingly criticised by the SSCLCA, writing that it is "naïve to expect that a phrase such as 'public interest' can be administered properly by public servants, who clearly have an interest in non-disclosure" (SSCLCA 1979, p. 221). And as late as 1995, the ALRC noted that "it is not uncommon for agencies to issue a conclusive certificate after an applicant has lodged an appeal with the AAT . . . consider[ing] this practice to be an abuse of the certificate provisions" (ALRC, 1995, para. 8.20). Nevertheless, the FOI Act passed with these restrictive practices intact. However, they were consistently criticised through arguments that "highly sensitive information, release of which would not harm the public interest but which would precipitate a public accountability debate, is exactly the sort of material to which the 
FOI Act is designed to give access because it involves responsibility at the very highest levels of government" (ALRC, 1995, p. 79). Ultimately it was not until the reforms of 2009-2010 that conclusive certificates were abolished.

\subsection{Extending the reforms}

The importance of the freedom of information (and other) reforms of 2010 must be seen within the context of the consequences of other legislation, administrative decisions and amendments, and the disruptive technologies of the digital age. These consequences give rise to conflicting attitudes and tensions not only between government and citizens, but also between idealism and pragmatism within government itself, often between opposing political parties. For example, with the introduction of FOI legislation there was a surge of requests for information, reaching over 35,000 in its third year, leading to one bureaucrat suggesting that "users of the legislation should be required, where appropriate, to contribute towards meeting its cost" (Attorney General's Department, 1987, p. 69). However, at the same time another lamented that "it is to be hoped that business interests will come to seek access to more of the non-sensitive, but commercially useful information held by government. There is little sign outside one or two major newspapers that the media are interested in using the Act to gain more detailed information on the context and implications of Government actions" (Attorney General's Department, 1987, p. iv).

In the twenty-seven years between the introduction of legislation concerning access to government information and the major reforms of 2009-2010, there were numerous amendments, mainly administrative or for clarification. But for the most part they were relatively minor, notwithstanding the introduction of application fees in 1986, and in the opinion of Daniel Stewart, "did little to alter the basic structure and operation of the act and if anything they reflect increased resistance to the disclosure of government information" (2015, p. 104). During this period there were two inquiries into the FOI Act conducted by the 
Australian Law Reform Commission: Open government: A review of the Federal Freedom of Information Act 1982 (1995), and Secrecy laws and open government (2008).

The first, initiated by a Labor Government, had a brief "to extend as far as possible the right of the Australian community to access to information in the possession of the Government of the Commonwealth ... [and] to improve the quality of decision making by government agencies in both policy and administrative matters by removing unnecessary secrecy surrounding the decision-making process" (ALRC, 1995, p. 5). The report, which made 106 recommendations for reform, was tabled after the government changed hands. The new Liberal government made no response, instead requesting in 2004 a comprehensive review to examine "the operation of existing mechanisms designed to prevent the unnecessary disclosure of classified material or security sensitive material in the course of criminal or other official investigations and court or tribunal proceedings of any kind" (ALRC, 2004, p. 5). When the Labor party returned to power in 2007, it initiated another inquiry into the FOI legislation, this time acknowledging in its terms of reference, the legitimacy of keeping secrets in certain circumstances and of "the importance of balancing the need to protect Commonwealth information and the public interest in an open and accountable system of government; and [that] previous reports (including previous reports of the Commission) that have identified the need for reform in this area" (ALRC, 2009, p. 5).

The 1995 and 2009 inquiries into the status of FOI in Australia concluded that there was a continuing problem of state secrecy:

the Review considers that more must be done to dismantle the culture of secrecy that still pervades some aspects of Australian public sector administration ... [and] the conflict between the old 'secrecy regime' and the new culture of openness represented by the FOI Act has not been resolved (ALRC, 1995, pp. 7, 14) and that 
official secrecy has a necessary and proper province in our system of government. A surfeit of secrecy does not (Bennett v President 2003, quoted in ALRC, 2009, p. 25)

The 2009 report, which reiterated many of the same recommendations of the 1995 report, was delivered in November 2009, although two exposure draft bills had been introduced the preceding month, specifically the Removal of Conclusive Certificates and the Information Commissioner Bills. The Freedom of Information Amendment (Reform) Act was introduced two weeks later. In 2010 it and the associated bills became law. The major provisions of this package of legislation were the removal of ministerial conclusive certificates, to be replaced by two categories of exemptions to disclosure; 1) unconditional exemptions for sensitive material, and 2) conditional exemptions, based on a single public interest test (Table 1); the removal of FOI application and internal review fees; and the creation of the Office of the Information Commissioner (OAIC), which has responsibility for FOI.

\begin{tabular}{ll}
\hline Unconditional exemptions & Conditional exemptions \\
\hline s 33 affecting national security, defence or international relations & s 47B Commonwealth-State relations \\
s 34 cabinet documents & s 47C deliberative processes \\
s 37 affecting enforcement of law and protection of public safety & s 47D financial or property interests of the Commonwealth \\
s 38 secrecy provisions & s 47E certain operations of agencies \\
s 42 subject to legal professional privilege & s 47F personal privacy \\
s 45 containing material obtained in confidence & s 47G business (to which s 47 applies) \\
s 45 A Parliamentary Budgetary Office documents & s 47H research \\
s 46 which would be contempt of Parliament or court & s 47H the economy \\
s 47 disclosing trade secrets or commercially valuable information & \\
s $47 \mathrm{~A}$ electoral rolls and related documents & \\
\hline
\end{tabular}

Table 1 The unconditional and conditional exemptions under the FOI reforms of 2010

\subsection{Owning the Information}

I have already noted that all government information in Australia is the property of the Crown, but Gilchrist asks the question "does this role as proprietor of copyright material 
conflict with the principle that all citizens in a modern liberal democratic society should have fair and open access to government information?" (Gilchrist, 2012, p. 74). This is a legitimate question since the current Freedom of Information Act states "information held by the Government is to be managed for public purposes, and is a national resource", which might be construed as custodianship rather than ownership. ${ }^{2}$ The government, in its response to the Government 2.0 taskforce, released guidelines on licensing public sector information [PSI] for Australian government agencies that stated that "PSI can be thought of as material with the essential purpose of providing Government information to the public. A wide interpretation should be given to material in which the Commonwealth owns the copyright" (Attorney General's Department, 2011, p. 1). Within the context of this paper, there are two regulatory amendments which, while not contesting the legitimacy of Crown copyright, enable further openness; both are a direct consequence of the disruptive technologies of the Web. The first is the memorandum of the Australian Government Information Management Office (AGIMO) Circular 2010/001, which enabled the archiving of government websites. The other is the 2010 Statement of Intellectual Property Principles for Australian Government Agencies, which had particular application to the re-use of government information, including government datasets.

The move by governments to publish government information on their websites allowed a greater degree of public access to documentary materials and therefore, in theory, enabled circumvention of onerous FOI application processes. However websites are notoriously dynamic and material is often removed on a time-based schedule, or simply 'disappears'. This is not to automatically insinuate secrecy when material is taken down, but when material

\footnotetext{
2 The Copyright Law Review Committee recommended that "copyright in certain materials produced by the judicial, legislative and executive arms of government be abolished" (p. xxvi). Copyright Law Review Committee. (2005). Crown copyright report. Barton, ACT: Copyright Law Review Committee.
} 
or policy statements contradictory to past or present attitudes is removed, as in the current case of the Trump administration's removal of climate change reports from the Environmental Protection Agency website (Congressional Record, 16 February 2017, S1251), website archiving continues to provide access. In Australia, under the Archives Act 1983 government websites are considered official records and therefore copies must be sent to the National Archives whenever major changes are made, however access to these copies are limited to the open access period. Since 2011 the National Library of Australia has also been archiving Commonwealth government websites. However, under copyright law archiving is an act of re-publishing and therefore requires permission from the owner, a process that the National Library (2012, p. 3) notes requires "labour intensive negotiation with each publisher for the rights to collect, preserve and provide access". The AGIMO memorandum provided a solution to this problem by permitting the library "to collect, preserve and make accessible in perpetuity Commonwealth Government online (digital) publications and websites [by] simplify[ing] administrative procedures by removing requirements to obtain prior permissions" (AGIMO, 2010). This regulatory change circumvents the 30 year rule by providing immediate open access to the content of government agencies' websites through the Australian Government Website Archive (AGWA).

By the early 2000's there were increasing demands for access to government datasets in order to see the data on which government decisions were made (Eaves, 2010), and to be able to re-use that data to create new privately-held and commercial applications using new technical analytical tools. Both cases challenged the intellectual property laws; ownership could dictate disclosure or non-disclosure, and the terms of its use — read only or re-use for any purpose. Section 11(b) of the 2010 Statement of Intellectual Property Principles addressed these issues stating that "consistent with the need for free and open re-use and 
adaptation, public sector information should be licensed by agencies under the Creative Commons BY standard as the default . . . or other open content licences”. Furthermore, when "Commonwealth records become available for public access under the Archives Act 1983, public sector information covered by Crown copyright should be automatically licensed under an appropriate open content licence" (Attorney General's Department, 2010, p. 6). The challenging question of what data is selected to be disclosed and why is discussed in the next section.

\section{Reform impact and vestiges of secrecy}

There is no doubt that the most profound change to counter government secrecy was the introduction of the Freedom of Information legislation; the very fact that a citizen could request access to government information was an enormous step. And while the FOI reforms of 2010 arguably had the greatest impact, it is difficult to explore this without reference to other concurrent reforms. For example, the changing of the status of Crown copyright to reuse under a Creative Commons license, an important driver for the release of open government data (OGD), provided me with access to the historical datasets of FOI requests, costs and charges, instead of having to 'scrape' it from 23 years of printed annual reports. Of greater importance, the change to a usage licence is often the basis on which datasets are released. According to agency responses to the survey of OGD implementation under a Creative Commons licence, there were concerns it "would compromise a potential revenue stream for the agency", or in the case of those agencies already selling data such as scientific survey and monitoring data, it "would compromise the value and profitability of a saleable asset" (OAIC, 2013, p. 23). This monetisation of public information does not accuse government of secrecy, but it does raise questions about the degree of openness of OGD. As Gilchrist notes, "once a decision is made to release information it is still open to government to 'push' information freely, or to limit access in some ways through price, licensing 
arrangements and media" (Gilchrist, 2012, p. 148). It also prevents disclosure of information and datasets under unconditional and conditional exemptions of FOI legislation, which includes information labelled 'commercial in confidence'. The data shows that in the period 2011-2017 there were 633 unconditionally exempt (trade secrets or commercially valuable information) requests and 1,821 (business and the economy) that were conditionally exempt requests (FOI Annual Returns 2000-2015).

The Australian Information Commissioner Act establishing OAIC has been integral to removing much of the secrecy surrounding government information. It is responsible for the implementation of the FOI legislation (and, incidentally, for the compilation and release of the FOI datasets). The Explanatory Memorandum of FOI Act states

the Australian Information Commissioner, supported by the FOI Commissioner, will act as an independent monitor for FOI and will be entrusted with a range of functions designed to make the Office of the Australian Information Commissioner both a clearing house for FOI matters and a centre for the promotion of the objects of the FOI Act (p. 1) It is, as Popple (2014, p. 39) points out, an integrated model, combining FOI, privacy and information policy. One instance of information policy is to require all agencies to implement an information publication scheme (IPS) mandating information published on their websites. This includes publishing a disclosure log of FOI requests; the log contains the request number, the outcome (granted in full, partially granted or refused), the document(s), or a link to where it can be downloaded. On the whole, this is a reasonable step in transparency, but it has come in for criticism by journalists claiming that the almost immediate public publishing of disclosed FOI documents for which they have may paid hundreds of dollars in processing charges, not only benefits their competitors, but looks like a "deliberate disincentive" to making sensitive information public (Australian Broadcasting Corporation, 2015). 
We can debate the degree of commitment demonstrated by Australian political partiesthat the Australian Labor Party is the party of reform, championing more openness, the Australian Liberal Party taking a more conservative approach, more concerned with maintaining secretiveness (see Fig. 1). Certainly, this was true of the Liberal government under the Abbott prime ministerial leadership when in May 2014, and without any announcement, it quietly noted in the budget that funding the OAIC would cease on January $1^{\text {st }} 2015$, a measure that would save $\$ 10.2$ million over four years. The government criticised the OAIC system of appeals for being too complex and that the backlog was indicative of inefficiency (Brandis, 2014), although Popple contends that at the time of the budget delay was no longer a significant issue (2014, p. 37). The government proposed that the functions of OAIC would be transferred to other agencies and new arrangements for privacy and FOI regulation would commence from January 2015 (Australian Government, 2014). In October, it introduced legislation to repeal the Australian Information Commissioner Act, but languished in the Senate Legal and Constitutional Affairs Committee, ultimately lapsing in the prorogation of the Parliament in early 2016.

While the proposed repeal legislation was still in limbo, Peter Timmins, the current convenor of the Australian Open Government Network and advisor to Australia's membership of the Open Government Partnership, concerned about the proposed repeal of the Act, submitted an FOI application to OAIC for "[for] documents concerning discussions with the Attorney General's Department about the conduct of OAIC functions from 1 January 2015 including proposals put to or received from the Department concerning funding and staffing, and any agreement or understanding reached on these and related matter" (Timmins, 2015). Timmins noted in his application that the request was in the public interest, that "disclosure of documents concerning discussion about the conduct of these functions would advance public debate on this topic of current importance" (ibid.). The FOI agent 
found there were forty-four relevant emails among OAIC, the Human Rights Commission and the Departments of the Attorney-General and the Prime Minster and Cabinet. However, she considered them to be subject to the conditional exemption deliberative processes, on the basis that "the Bill has not passed through parliament [and] disclosure of the documents could reasonably be expected to impact on the ability of the OAIC to obtain full opinions and recommendations from relevant agencies" (ibid.). Thirteen were refused outright and thirtyone were so heavily redacted, that only the email trails and pleasantries could be read. One is left with impression that the administration was more interested in rolling back the 2010 reforms than the openness of government. And Timmins at the time noted "sadly AGD [Attorney-General's Department] now to be charged with responsibility for 'guidance' across the service are no FOI champions, based on what I've seen of their inventive reasoning from time to time" (2014 para. 2).

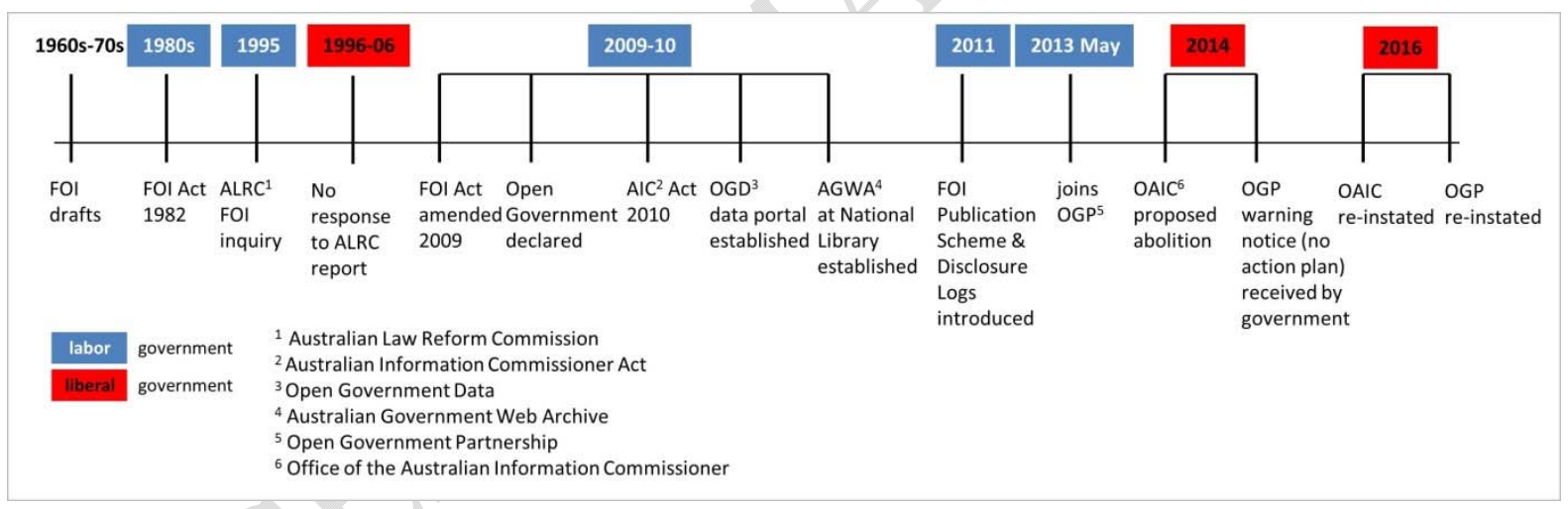

Fig. 1 Summary timeline of significant events in the ebb and flow of government openness reform

Tim Smith and two other former Supreme Court (Victoria) justices have argued this action of attempting to repeal the Australian Commissioner Act was unconstitutional; that the executive branch of government had claimed the constitutional power of Parliament. Whatever the legitimacy of this argument, there is no doubting the legitimacy of their comment that this "is deeply disturbing. Greater secrecy has been reintroduced. Government is now less transparent and accountable ... [h] aving failed to pass the legislative amendments that would have effected its purpose, the government has achieved the same result by the 
power of the purse" (Smith, Harper, \& Charles, 2015, para. 6). In a postscript to this controversial episode, the government, under a less conservative Liberal prime minister, allocated in its 2016-2017 budget $\$ 37$ million over the next four years to re-fund, effectively re-instating OAIC, three times the amount that had been declared "too expensive" (see Fig. 1).

To return to the Freedom of Information Act—various amendments to this Act affected the level of access to government-held information. Some have obvious causes including the imposition of and removal of application fees, and the availability of information published on government websites (Fig. 2). The introduction of FOI fees appears to have had similar effects in other countries; Roberts (1999) reported drastic reduction in the number of requests in Canada, particularly Ontario, and in Ireland after their introduction in 2003, the numbers of requests fell overall by $50 \%$ and by $75 \%$ for non-personal information (Information Commissioner of Ireland 2004, p.1). When more data was proactively published on the Web, in the reporting period 2007-2008 the number of requests decreased by 9,889 , a number directly attributable to the use of online and other informal channels, particularly for personal information (Attorney General's Department, 2008). 


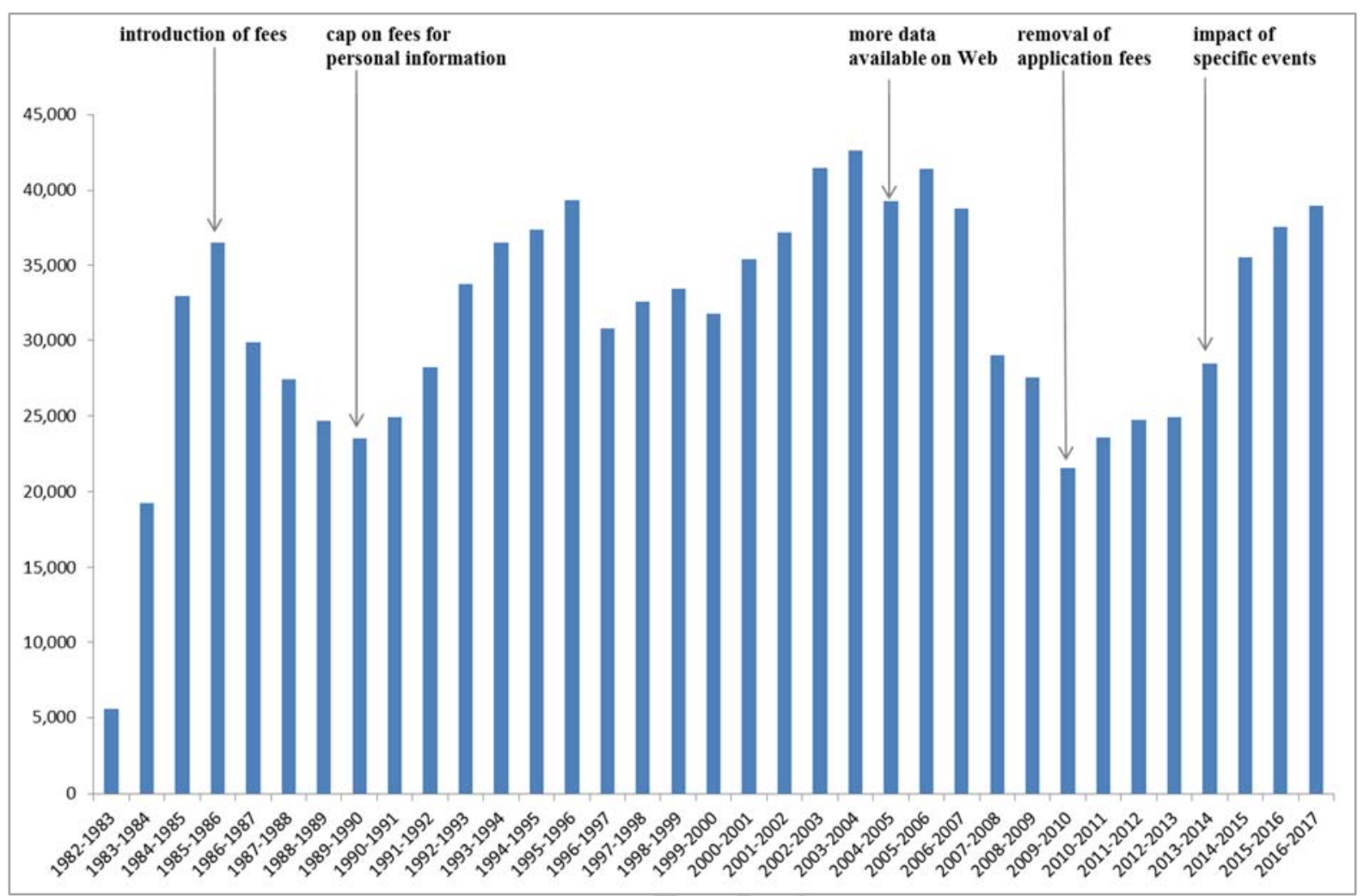

Fig. 2 Factors affecting general patterns of all FOI requests 1982-2017

(Data source: FOI requests, costs and charges, 1982-2017)

In the matter of charges for FOI requests, a review was carried out in 2012 (OAIC, 2012).

Amendments included abolishing application fees for requests and internal review and for processing requests for personal information. As in the early days of Australian FOI, there was the question of recovering costs, a practice one submission to the inquiry argued was "at odds with the idea that FOI legislation is about the fundamental right of individuals to access information" (ibid., p. 23).

Nevertheless, two decisions were made concerning costs. The first was to put a ceiling of 40 hours on processing time for policy-related requests, the first 5 of which were free. ${ }^{3}$ The second, named a 'practical refusal', allowed a discretionary charge to be levied under s 24 of the Act. This is a mechanism to prevent an unreasonable burden on the resources of an

\footnotetext{
${ }^{3}$ The current schedule of processing charges is search and retrieval (\$15 per hour), decision making (\$20 per hour), photocopying (10c per page), transcription ( $\$ 4.40$ per page), and supervised inspection ( $\$ 6.25$ per half hour).
} 
agency, but one which could be potentially open to manipulation. Under s 24(2), two or more similar requests can be treated as a single request and under s $24 \mathrm{AA}$, any request that is estimated to take more than 40 hours can be refused, or can incur a very high processing fee. It is easy see that if many individual requests can be deemed to be a single request that requires many hours for processing, individual applicants would refuse to pay the estimated fees and withdraw their applications.

The removal of application fees in 2010 is not the only factor accounting for the steady rise in requests in the post-reform period. Other factors to be considered are the removal of conclusive certificates and the impact of specific events such as an influx of refugees and asylum seekers. I have already noted the adverse effect of conclusive certificates on freedom of information; but their removal from the Act in the 2010 reforms and their replacement with conditional exemptions was not necessarily a panacea. These conditional exemptions (see Table 1 above) are subject to a single public interest test. Many applications for policyrelated information are therefore framed to be in the public interest, a concept not defined in legislation but left "necessarily broad and nonspecific because what constitutes the public interest depends on the particular facts of the matter and the context in which it is being considered" (OAIC, 2014, p. 3). It would seem that this reform has increased the potential for conflict with privacy. Since the reforms the largest category of documents conditionally exempted were on personal privacy grounds, that is, policy documents which, if released, would infringe personal privacy (Table 2).

\begin{tabular}{|c|c|c|c|c|c|c|c|}
\hline Exemptions & $\begin{array}{l}2011- \\
12\end{array}$ & $\begin{array}{l}2012- \\
13 \\
\end{array}$ & $\begin{array}{l}2013- \\
14\end{array}$ & $\begin{array}{l}2014- \\
15 \\
\end{array}$ & $\begin{array}{l}2015- \\
16 \\
\end{array}$ & $\begin{array}{l}2016- \\
17 \\
\end{array}$ & Totals \\
\hline Personal privacy & 630 & 785 & 785 & 804 & 779 & 886 & 4,669 \\
\hline $\begin{array}{l}\text { Certain operations of } \\
\text { agencies }\end{array}$ & 209 & 498 & 498 & 435 & 534 & 579 & 2,753 \\
\hline Business & 289 & 274 & 274 & 328 & 341 & 306 & 1,812 \\
\hline Deliberative processes & 225 & 286 & 286 & 270 & 275 & 345 & 1,687 \\
\hline Cth-State relations & 66 & 66 & 66 & 57 & 90 & 55 & 400 \\
\hline
\end{tabular}


Table 2 The top five categories of conditionally exempted policy-related documents 2011-2017

The following case is an example of the use of the practical refusal mechanism and conditional exemptions, not only personal privacy, but also certain operations of agencies, the two highest categories employed since 2011, to apparently circumvent openness and transparency of government actions.

I have already suggested that perhaps one of the factors driving the increase of FOI applications in this period was a set of specific external events, the arrival of asylum seekers coming to Australia by boats through people smuggling operations. Boats were capsizing or being towed back to sea, people were drowning, the situation was politicised in the general elections of 2010 and 2013 through the rhetoric of border protection and national security, heightened by the rhetoric of terrorism threats. By 2013 the offshore detention camps on Nauru and Manus Island were re-opened as part of a very hard line scheme, the Pacific Solution, in which it was declared that any asylum seeker, termed "illegal maritime arrivals" (IMA), who arrived by boat without a visa, would be denied resettlement in Australia. Towards the end of 2013 the government announced Operation Sovereign Borders, led by the Australian Defence Force, thus militarising the situation and placing much of the information out the ambit of FOI, and putting an embargo on commenting on on-water operations (Morrison, 2013). This treatment of asylum seekers was highly controversial, generating enormous criticism concerning the secrecy of the operation with newspaper articles and editorials such as "the government has made a fetish of secrecy ... the government has put a veil of secrecy around the way it is conducting Operation Sovereign Borders and the handling of illegal maritime arrivals . . the veil of secrecy has become a black hole of intrigue" ("Abbott stepped over the line in stopping boats," 2014). With reports of very bad conditions on Nauru and Manus Island filtering through, a Senate committee investigating the conditions on Nauru (2015, p. 124) concluded that given the "pervasive culture of secrecy which cloaks 
most of the department's activities in relation to the Nauru RPC, it believes that a far greater level of scrutiny, transparency and accountability is required".

According to the FOI annual returns, in the period after the FOI reforms the Immigration Department had received the most requests for policy-related information $(3,540)$ followed by the Australian Taxation Office $(3,038)$. The majority of those for the Immigration portfolio were refused on the grounds of personal privacy, certain operations of agencies and practical refusal (Fig. 3). Not coincidently there is a steep rise in the exemptions on personal privacy during the period of the election campaigning, but of concern is the steep rise of the practical refusal mechanism; of the total number (424) only 19.5 percent were subsequently processed. It is interesting to note after the election the use of practical refusal drops by over 100 percent and has remained fairly stable since.

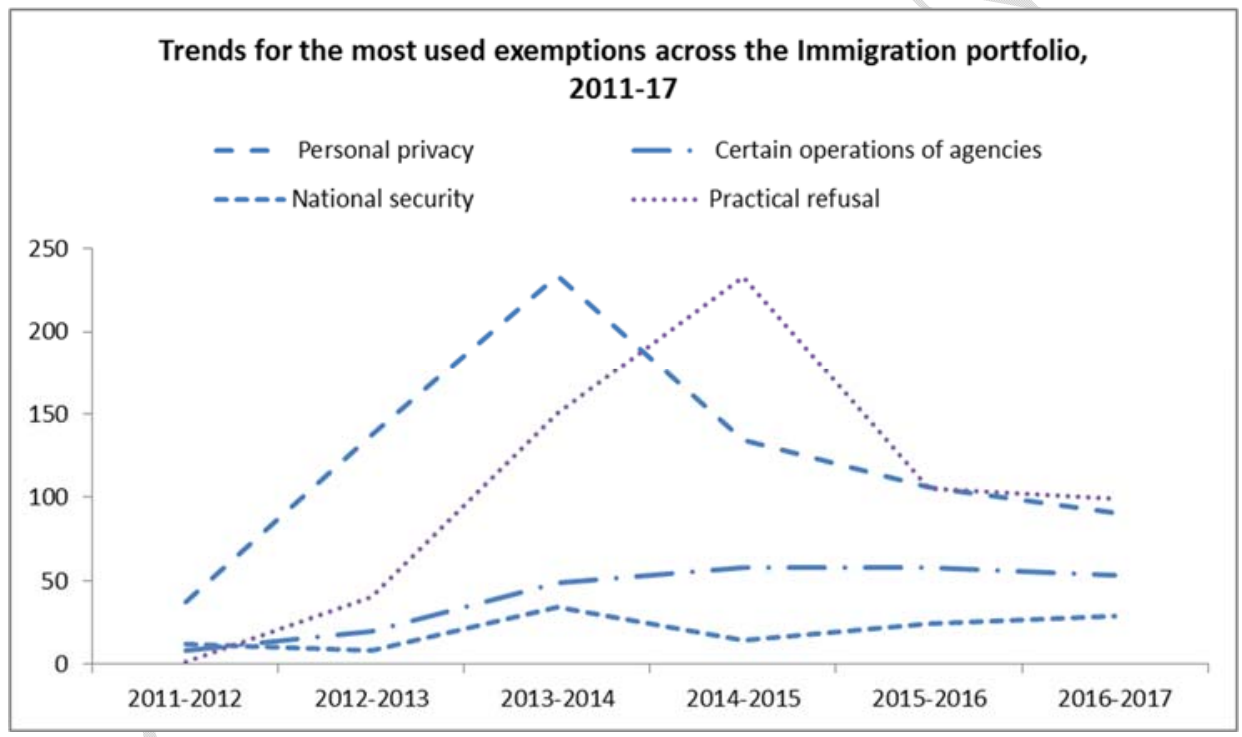

Fig. 3 Trends for the most used exemptions across Immigration portfolio 2011-2017 (Data sources: FOI Annual Returns 2000-2015)

Under the circumstances, it can be assumed that many people who were attempting to get information about the asylum seekers on Nauru were journalists, although the Immigration Department's FOI disclosure logs do not identify requests made by the media. However, through the Open Australia Foundation's FOI Right to Know project, journalists submitted over a hundred FOI requests concerning the Nauru detention centres. These were refused 
under s 24(2), and one was refused under both s 24(2) and s 24AA, stating it was estimated to take 57 hours to process (Farrell, 2013). The advisory document acknowledged that "the department recognises that there is a significant public interest in the welfare of clients in immigration detention. This, however, needs to be balanced against other public interests including, but not limited to, the expectation of all clients (and their families), including those individuals in immigration detention, that their personal information will be protected" (ibid., p. 3). Alastair Morrison (1997) complained about the bureaucratic games that are played to circumvent journalistic endeavours to get access to government information; it is not too farfetched to wonder if this is such a case. In a final note, in 2016, the documents Paul Farrell, a journalist at The Guardian, had requested were leaked to him. He and another Guardian journalist completely redacted all details that would identify the asylum seekers, the same criteria stipulated in the conditional exemption, personal privacy. The Nauru Papers, incident reports from the detention camp, cataloguing horrific conditions in the detention camp, were published in The Guardian (Farrell \& Evershed, 2016). The government made no formal comment.

\section{Discussion and conclusion}

Lawrence Quill (2014) considers that the period from the 1970s to the 1990s - the period of the initial open government reforms in Australia - represented a sea change in the culture of secrecy, delivered by the end of the Cold War, and catastrophes and scandals such as the Vietnam War and Watergate. I would argue that in Australia it was more the 2009-2010 series of reforms that changed much of the culture of secrecy widespread in the Australian government during the twentieth century. While a good deal of this was legislative and regulatory, other contributing influences were including journalists and civil society activists and a progressive government willing to enact a transparency agenda. The abolition or modification of the more abhorrent provisions of the FOI Act were achieved through 
amendments - ministerial vetoes and conclusive certificates and application fees were removed, some eight exemptions were designated as 'conditional', subject to a single public interest test, and mandatory publication of FOI disclosure logs was introduced. The concurrent and complementary new legislation, the Australian Information Commission Act which established OAIC (and subsequent re-instatement), along with changes to the Privacy and Archives Acts were also integral to the decrease of state secrecy.

Furthermore the ability for private citizens to be able to access and/or amend their personal information has been greatly enhanced; the FOI Annual Returns 2000-2017 show that an average of 70 percent of requests was granted in full. Policy-related requests, however, have not been so generously treated, with an average of only 39 percent, although for those requests that are partially granted, it is hard to judge the amount of redaction in the documents. Disturbingly, based on the FOI data concerning policy-relation information, it appears that secrecy is now increasing (Fig. 4), possibly confirming the contentions of Snell (2001) and Luscombe and Walby $(2017$, p. 4) that governments may use FOI as an obfuscating mechanism to maintain secrecy while providing "a veil of legitimacy". This increase in government information secrecy and resistance to transparency policies is reflected in international trends, in part caused by the rise of terrorism (Kreimer, 2008; Roberts, 2014). 


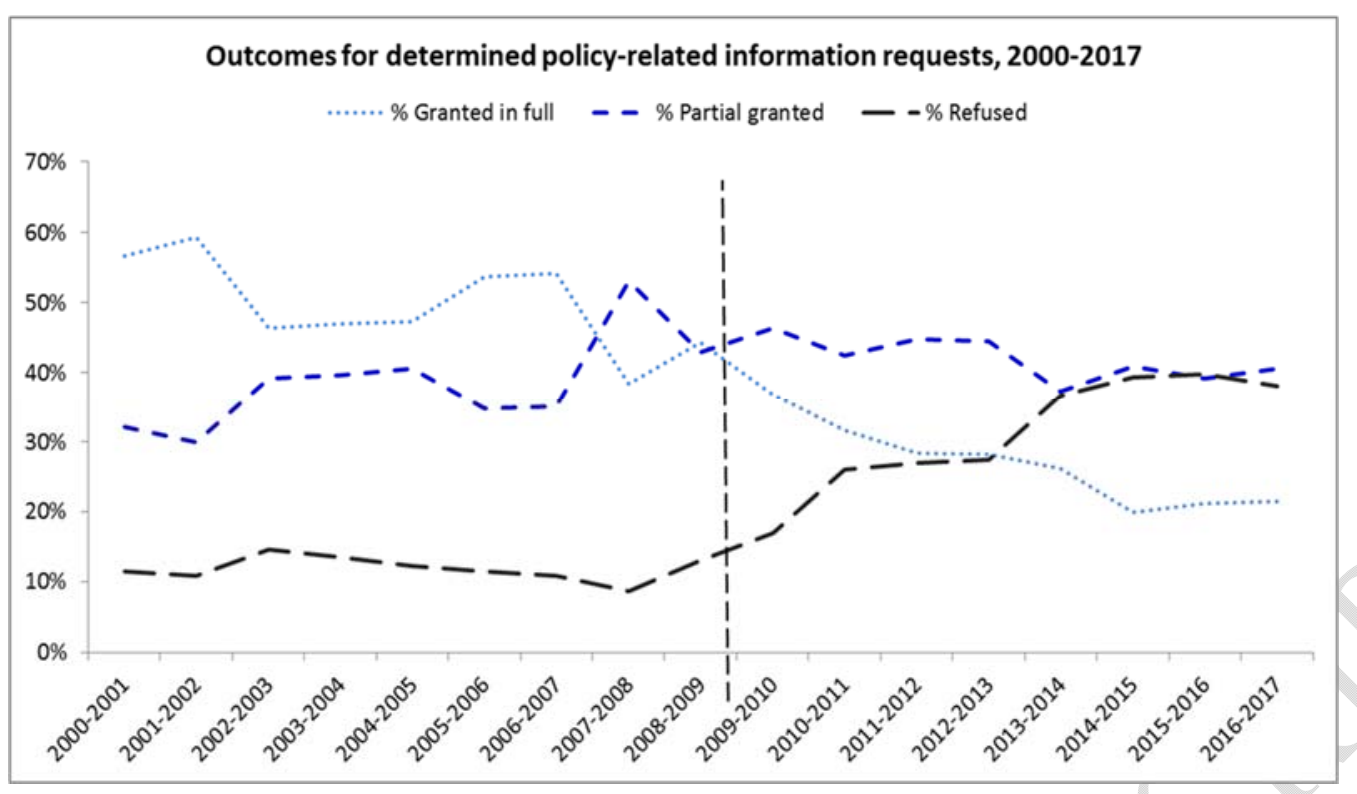

Fig. 4 Outcomes for policy-related information requests before and after the FOI reforms of 2009-2010 (Data sources: FOI Annual Returns 2000-2017)

There are serious questions concerning ownership of government-held information, its management as a national resource and the need to balance the right to privacy and the right to information. The Universal Declaration of Human Rights (1948) recognises that privacy is a human right, which has been interpreted as including the right to ascertain what personal information is stored by governments and for what purposes (Bygrave, 1998). Even if we take at face value the government statements that there is public ownership of government information and that their responsibility is one of custodianship (OAIC, 2010, p. 51), it cannot be assumed that the individual citizen has ownership of his or her government-held personal information. Nevertheless, FOI legislation ensures that an applicant cannot be denied access to his or her own information, allowing it to be annotated and amended, unless it is exempted on grounds of secrecy, such as the records held by ASIO (Australian Security Intelligence Organisation.

The freedom of information and privacy legislation does differentiate between an applicant's own personal information and personal information that is held in third party documents. The FOI personal privacy conditional exemption protects the privacy of individuals whose information is recorded in documents requested under FOI. The decision 
on disclosure rests on whether the individual is 'reasonably identifiable' in the document. This will depend on the context and circumstances, where it may be technically possible to identify individuals from information it holds, due to consideration of the cost, difficulty, practicality, it may not be practically possible (Egan \& Shera, 1952, p. 61). Non-disclosure of privacy (personal) information for reasons of national security or public safety (two of the unconditional exemptions), is obviously legitimate, but exploiting this legitimacy for bureaucratic secretive purposes is an abuse of power. This appears to be the case in the Immigration Department's withholding disclosure of information concerning the detention centres on Nauru and Manus Island, since the documents requested refer to the asylum seekers only as 'person in detention' or by an IMA number.

While this paper in no way intends to conflate secrecy and privacy, there is also the question of the use of conditional exemption deliberative processes. A common argument for not disclosing documents of deliberation was the inhibition of frankness and candour (re Howard and the Treasurer1985), an argument that intimates that deliberations should be private. However, the 2010 reform extended that range of public interest factors and noted "agencies should be cautious in applying [earlier] precedents" (OAIC, 2016, p. 15). In a decision in the Administrative Appeals Tribunal, Deputy President Forgie agreed with the Information Commissioner that it is an "essential balance that must be struck between making information held by government available to the public so that there can be increased public participation leading to better informed decision-making and increased scrutiny and review of the government's activities and ensuring that government may function effectively and efficiently" (Wood; Secretary, Department of Prime Minister and Cabinet and (Freedom of Information) [2015], at 69).

In conclusion, in forty years Australia has changed from a country in which access to government information was firmly restricted by official secrecy, to one which accepts that 
openness of government is fundamental to a healthy democracy. This has been achieved by a series of far-reaching reforms that have created an environment where citizens expect to be able to know how and why policy decisions are made, and in which governments assert its information is a national resource which it manages for the democratic good. Much of this information is 'pushed' to citizens through web publications and government data portals. A great deal more is still hidden from immediate scrutiny for legitimate reasons, such as national security, public safety, and the need to have frank discussions for planning and decision-making. This paper has examined the impact of these reforms and the potential for conflict, particularly between the right to know and personal privacy, and on balance, it must be said they have achieved a diminution of a culture of secrecy. Whether the recent rise of destabilising events such as mass refugee migrations, terrorism threats or an increasing rate of disruptive technologies will lead to a reduction in the openness of governments, remains to be seen. However, when a politician comments that "legislative amendments, when there is need for them, are fine, but governments with their control over the information in their possession can always find ways to work the legislation to slow or control disclosure" (Brandis in Australian Senate Debates 2009, p. 4849), there is still much more to be achieved.

\section{References}

Abbott stepped over the line in stopping boats. (2014, 9 July 2014). Sydney Morning Herald. Attorney General's Department. (1987). Freedom of Information Act 1982 : 1986-87 Annual report by the Attorney-General on the operation of the Act. Canberra, ACT.

Attorney General's Department. (2008). Freedom of Information Act 1982 Annual Report 2007-2008. Canberra, ACT.

Attorney General's Department. (2010). Statement of Intellectual Property Principles for Australian Government Agencies. Retrieved from 
ment $\% 20$ of $\% 20 \mathrm{IP} \% 20$ Principles $\% 20$ for $\% 20$ Australian $\% 20$ Government $\% 20$ Agencies

2.pdf. Accessed 8 June 2016.

Attorney General's Department. (2011). Guidelines on Licensing Public Sector Information for Australian Government Agencies. Retrieved from https://www.finance.gov.au/files/2011/02/Draft-Guidelines-on-Licensing-Public-

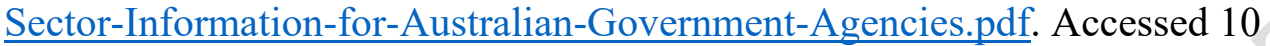
September 2017.

Australia. Senate. (2009). Debates. No. 8, 13 August, p. 4850.

Australia. Senate Select Committee on the Recent Allegations Relating to Conditions and Circumstances at the Regional Processing Centre in Nauru. (2015). Taking responsibility: conditions and circumstances at Australia's regional processing centre in Nauru. Canberra, ACT: Commonwealth of Australia.

Australia. Senate Standing Committee on Constitutional and Legal Affairs (SSCCLA), (1979). Freedom of information: report by the Senate Standing Committee on Constitutional and Legal Affairs on the Freedom of information bill 1978, and aspects of the Archives bill 1978. Canberra, ACT: Australian Government Publishing Service.

Australian Broadcasting Corporation (2015). The problem with Freedom of Information in Australia. An interview with Michael McKinnon, FOI editor for the Australian Broadcasting Corporation, [interview by Richard Aedy] 12 March. Retrieved from http://www.abc.net.au/radionational/programs/mediareport/the-problem-with-foilaws-in-australia/6308022. Accessed 20 August 2016.

Australian Government. (2014). Budget measures: budget paper no. 2 2014-15. Retrieved from http://www.budget.gov.au/201415/content/bp2/download/BP2 consolidated.pdf. Accessed 10 June 2016. 
Australian Government Information Management Office (AGIMO). (2010). Whole of Government Arrangements for the National Library of Australia (NLA) to Collect, Preserve and Make Accessible in Perpetuity Commonwealth Government Online (Digital) Publications and Websites. Canberra, ACT: Deparment of Finance and Deregulation. Retrieved from http://www.finance.gov.au/sites/default/files/2010001_AGIMO_Circular_NLA_Digital_Preservation.pdf. Accessed 8 June 2015. Australian Law Reform Commission (ALRC). (1983). Privacy. Canberra, ACT: Australian Government Publishing Service.

Australian Law Reform Commission (ALRC). (1995). Open Government - A Review of the Federal Freedom of Information Act 1982 (pp. unpaged). Canberra, ACT: Australian Government Publishing Services.

Australian Law Reform Commission (ALRC). (2004). Keeping secrets: The Protection of Classified and Security Sensitive Information. Sydney, NSW: Australian Law Reform Commission.

Australian Law Reform Commission (ALRC). (2009). Secrecy laws and open government in Australia. Sydney, NSW: Australian Law Reform Commission.

Brandis, G. (2014). Streamlined arrangements for external merits review [Press release].

Retrieved from

https://www.attorneygeneral.gov.au/Mediareleases/Pages/2014/SecondQuarter/13Ma y2014-Streamlinedarrangementsforexternalmeritsreview.aspx. Accessed 10

September 2016.

Brown, G. (2007). On Liberty [speech] 25 October, BBC News. Retrieved from http://news.bbc.co.uk/2/hi/uk_politics/7062237.stm. Accessed 8 June 2017. 
Bygrave, L. A. (1998). Data protection pursuant to the right to privacy in human rights treaties. International Journal of Law and Information Technology, 6(3), 247-284. https://doi.org/10.1093/ijlit/6.3.247

Campbell, E. (1967). Public Access to Government Documents. Australian Law Journal, 41, 73-89.

Castells, M., \& Cardoso, G. (2006). The network society: From knowledge to policy: Johns Hopkins Center for Transatlantic Relations Washington, DC.

Copyright Law Review Committee. (2005). Crown copyright report. Barton, ACT: Copyright Law Review Committee.

Cunningham, A. (2005). Archival institutions. In S. McKemmish, M. Piggott, B. Reed \& F. Upward (Eds.), Archives: recordkeeping in society (pp. 21-50): Charles Sturt: Centre for Informatiion Studies.

Derrida, J. (1996). Archive Fever (E. Prenowitz, Trans.). Chicago: University of Chicago Press.

Eaves, D. (2010). After the collapse: Open government and the future of civil service. In D. Lathrop \& L. Ruma (Eds.), Open government: Collaboration, transparency, and participation in practice (pp. 139-150). Sebastopol, Calif.: O'Reilly Media.

Egan, M. E., \& Shera, J. H. (1952). Foundations of a Theory of Bibliography. Library Quarterly, 22(2), 125-137. https://doi.org/10.1086/617874

Farrell, P. (2013). FOI request for detail incident report 1-78LBQ9. from https://www.righttoknow.org.au/request/foi_request_for_detail_incident_119

Farrell, P., \& Evershed, N. (2016, 10 August 2106). What are the Nauru files?, The Guardian.

Finn, P. (1991). Official Information, Integrity in Government Project. Canberra: Australian National University. 
Gilchrist, J. S. (2012). The government as proprietor, preserver and user of copyright material under the Copyright Act 1968 (CTH). (PhD), Queensland University of Technology.

Grande, J. (2014). William Cobbett, the Press and Rural England: Radicalism and the Fourth Estate, 1792-1835. London UK: Palgrave Macmillan.

Greenleaf, G., \& Nolan, J. (1986). The deceptive history of the'Australia Card'. The Australian Quarterly, 58(4), 407-425. https://doi.org/10.2307/20635401

Gruen, N. (2009). Engage: Getting on with Government 2.0: Report of the Government 2.0 Taskforce Australian Government Information Management Office. Canberra, ACT: Department of Finance and Deregulation.

Hawke, A. (2013). Review of the Freedom of Information Act 1982 and Australian Information Commissioner Act 2010. Canberra, ACT: Attorney General's Department Retrieved from https://www.ag.gov.au/Consultations/Documents/FOI\%20report.pdf. Accessed 25 August 2016.

Hazell, R., \& Worthy, B. (2010). Assessing the performance of freedom of information. Government Information Quarterly, 27(4), 352-359. http://dx.doi.org/10.1016/j.giq.2010.03.005

Information Commissioner of Ireland (2004). Review of the Operation of the Freedom of Information (Amendment) Act 2003. Dublin: Office of the Information Commissioner. Retrieved from http://www.oic.ie/publications/specialreports/investigations-and-compliance-reports/Review-of-the-Operation-of-theFreedom-of-Information-Amendment-Act-2003.pdf Accessed 13 April 2015. Julnes, P. d. L., \& Holzer, M. (2001). Promoting the utilization of performance measures in public organizations: An empirical study of factors affecting adoption and 
implementation. Public Administration Review, 61(6), 693-708.

https://doi.org/10.1111/0033-3352.00140.

Kreimer, S.F. (2008). The Freedom of Information Act and the ecology of transparency, University of Pennsylvania Journal of Constitutional Law, 10, 1011-80.

Luscombe, A., \& Walby, K. (2017). Theorizing freedom of information: The live archive, obfuscation, and actor-network theory [in press]. Government Information Quarterly. https://doi.org/10.1016/j.giq.2017.09.003.

Macfarlane, L., \& Antsoupova, T. (2013). The Archives Act 1983 - A Legal Framework for a Digital Future? Paper presented at the Australian Society of Archivists 2013 Conference 15-18 October, Canberra. Retrieved from https://www.archivists.org.au/documents/item/465. Accessed 8 June 2016.

May, C. (2007). Digital rights management : the problem of expanding ownership rights. Oxford: Chandos.

McGinness, J. (1990). Secrecy Provisions in Commonwealth Legislation. Federal Law Review, 19, 49-97.

Morrison, A. (1997). The games people play: journalism and the Official Information Act. Paper presented at the Legal Research Foundation, The Official Information Act: Seminar Papers General Overview of Official Information and the Official Information Act. Wellington, NZ: Legal Research Foundation, 30-8.

Morrison, S. (2013). Operation Sovereign Borders update [press release]. Retrieved from http://web.archive.org/web/20131119002943/http://www.minister.immi.gov.au/media /sm/2013/sm209431.htm. Accessed 18 August 2016.

National Archives of Australia. (n.d.). Your story, our history: Timeline. from http://www.naa.gov.au/about-us/organisation/history/timeline.aspx. Accessed 10 June 2017. 
National Library of Australia. (2012). Submission by the National Library of Australia to the consultation paper Extending Legal Deposit. Retrieved from http://www.ag.gov.au/Consultations/Pages/ExtendingLegalDeposit.aspx. Accessed 25 August 2015.

Office of the Australian Information Commissioner (OAIC). (2010). Towards an Australian Government Information Policy, Issues Paper 1. Canberra, ACT Office of the Australian Information Commissioner (OAIC). (2011). Principles on open public sector information. Canberra: Office of the Australian Information Commissioner. Retrieved from http://www.oaic.gov.au/images/documents/information-policy/information-policyreports/Principles open public sector info report may2011.pdf. Accessed 10 September 2015.

Office of the Australian Information Commissioner (OAIC). (2012). Review of charges under the Freedom of Information Act 1982: Report to the Attorney-General. Canberra, ACT. Retrieved from https://www.oaic.gov.au/freedom-of-information/foiresources/foi-reports/review-of-charges-under-the-freedom-of-information-act-1982. Accessed 10 September 2016.

Office of the Australian Information Commissioner (OAIC). (2013). Open public sector information: from principles to practice: Report on agency implementation of the principles on open public sector information. Canberra, ACT: Office of the Australian Information Commissioner (OAIC).

Office of the Australian Information Commissioner (OAIC). (2014). Guidelines issued by the Australian Information Commissioner under s93A of the Freedom of Information Act 1982 [revised Oct 2014]. Canbera, ACT: Australian Government. Office of the Information Commissioner (OAIC). Retrieved from 
https://www.oaic.gov.au/resources/freedom-of-information/foi-

guidelines/FOI_Guidelines___new_compilation___Oct_2014.pdf. Accessed 8 June 2016.

Office of the Australian Information Commissioner (OAIC). (2016). FOI requests, costs and charges 1982-2015 [dataset]. Retrieved from: http://data.gov.au/dataset/freedom-ofinformation-statistics/resource/7816ff5f-96ec-4c5a-a26b-312bda2245db.

Office of the Australian Information Commissioner (OAIC). (2016). FOI Guidelines. Part 6 Conditional exemptions: Australian Government. Office of the Information Commissioner (OAIC).

Office of the Australian Information Commissioner (OAIC). (n.d.). History of the Privacy Act. Retrieved from https://www.oaic.gov.au/about-us/who-we-are/history-of-theprivacy-act. Accessed 10 September 2017.

Office of the Australian Information Commissioner (OAIC). (unknown). FOI annual returns data [2011-2015] [datasets]. Retrieved from: http://data.gov.au/dataset/freedom-ofinformation-statistics/

Paterson, M. (2005). Freedom of information and privacy in Australia: Government and information access in the modern state (Vol. 2). Chatswood: LexisNexis Butterworths Popple, J. (2014). The OAIC FOI Experiment. AIAL Forum (78), 31-43.

Quill, L. (2014). Secrets and democracy: From Arcana Imperii to Wikileaks. New York, NY: Palgrave Macmillan.

Roberts, A. (1999). Retrenchment and freedom of information: recent experience under federal, Ontario and British Columbia law. Canadian Public Administration, 42(4), 422-51. http://doi.org/10.1111/j.1754-7121.1999.tb02035.x

Roberts, A. (2014). Making transparency policies work: The critical role of trusted intermediaries. Presented at the International Seminar on Accountability and 
Corruption Control, 21 October 2014, Mexico City. Retrieved from

http://dx.doi.org/10.2139/ssrn.2505674. Accessed 10 September 2017.

Smith, T., Harper, D., \& Charles, S. (2015, 26 May 2015). Abbott government skirts

Parliament and muzzles the FOI watchdog, Sydney Morning Herald.

Snell, R. (2001). Administrative Compliance-evaluating the effectiveness of freedom of information. Freedom of Information Review, 63, 26-32. Retrieved from https://papers.ssrn.com/sol3/papers.cfm?abstract id=2540700. Accessed 6 June 2016.

Stewart, D. (2015). Assessing Access to Information in Australia: The impact of freedom of information laws on the scrutiny and operation of the Commonwealth government. In J. Wanna, E. A. Lindquist \& P. Marshall (Eds.), New Accountabilities, New Challenges (pp. 79-158). Canberra, ACT: Australian National University Press.

Taylor, G. (2000). Why is there no Common Law Right of Privacy. Monash University Law Review, 26, 235.

Thynne, I., \& Goldring, J. (1981). Government "responsibility" and responsible government. Politics, 16(2), 197-207. https://doi.org/10.1080/00323268108401800

Timmins, P. (2014, 13 May 2014). Vale OAIC, you never had much of a chance. Retrieved from http://foi-privacy.blogspot.com.au/2014/05/vale-oaic-you-were-never-hadmuch-of.html\#.Wau86MgjHD4. Accessed 10 September 2017.

Timmins, P. (2015). Conduct of functions of OAIC from 1 January 2015. Retrieved from https://www.righttoknow.org.au/request/conduct of functions of oaic fro. Accessed 8 June 2016.

Weber, M. (1946, 2009). Essays in sociology. Translated, edited and with an introduction by HH Gerth and C. Wright Mills. New York: Routledge. 
Whitlam, G. (1972). Men and women of Australia. Retrieved from http://whitlamdismissal.com/downloads/72-11-13 whitlam-policy-speech podiumversion.pdf. Accessed 8 June 2016.

Wood; Secretary, Department of Prime Minister and Cabinet and (Freedom of Information [2015], No. AATA 945 (8 December 2015), Administrative Appeals Tribunal.

Retrieved from http://www.austlii.edu.au/. Accessed 13 July 2017.

Worthy, B. (2017). The politics of freedom of information: how and why governments pass laws that threaten their power: Manchester University Press. 